\title{
Ukrainian Students in Polish Schools: Selected Aspects of Adaptation on the Example of the City of Lublin
}

\begin{abstract}
The objective of this study is to present the opinions of Ukrainian secondary school students, living in a boarding school in Lublin, on their adaptation to the new environment while studying in Poland. The questionnaire method was used, which offered an insight into particular aspects of adaptation for their studying abroad, e.g., coping with being parted from their family, managing free time, adjusting to the new educational environment, viewing the Polish society, as well as observing differences and similarities between the Polish and Ukrainian culture.

The collected data point to a need to intensify educational activity promoting the space of mutual understanding between the citizens of the neighbouring countries. The problems revealed in this study show that the educational migration of Ukrainian students to Poland requires implementing a long-term and systemic educational policy that would shape multicultural competence of the Polish society.
\end{abstract}

\section{Keywords:}

adaptation, foreigners in Poland, multicultural education, Ukrainians in Poland

\section{INTRODUCTION}

Culture, defined by G. Hofstede (2007, p. 17) as "collective programming of the mind, which differentiates members of one group from another", is determined through the process of socialisation by institutions such as family, school, or conland.

Faculty of Pedagogy and Psychology, Maria Curie-Skłodowska University in Lublin, PoE-MAIL: agata.swidzinska@poczta.umcs.lublin.plＯRCID: 0000-0002-2185-7420 
tacts with peers. Socio-cultural determinants of how the youth functions within their own culture shape the development of their learning strategies when located in a different cultural space. The issue was studied by Krystyna Błeszyńska (2012), who concluded that "children and teenagers growing up in different cultural environments share certain universal needs, experiences, emotions, and social situations. Educational practice and environmental patterns that they are exposed to lead to a specific approach towards those events, values, situations, which makes them define their points of reference in different ways. They express their needs and interests in different ways. What is also different is their learning style and way of communicating with the environment” (p. 518).

The course of contacts between cultures is not unequivocal but rather multilayered and sensitive. The emerging spaces need to be identified and accustomed to for their potential to be released. It is of great importance in the context of education of foreign students. If teachers do not identify cultural differences, their students may not fully understand the instructions used in a specific cultural context, which may in turn lead to miscommunication, poor results and bad behaviour in class.

In order to boost the optimal academic achievement, teachers should understand their students' culture, support them during the process of school adaptation, also throughout acculturation. As was highlighted by Jerzy Nikitorowicz (2017), among many factors that shape human development and culture, one should not forget about "the notions of acculturation and transculturation, viewed as results of mobility and migration in the world, and the issue of finding oneself in a new place, a new culture, which triggers a complicated process of internal adaptation and set about acculturation mechanisms. These may focus on new tasks, stimulate to make an effort and consequently promote an effective participation in another culture. However, they may also lead to avoidance strategies, apparent activity, escapism, and being closed off within one's culture, or alternatively, it may lead to defiance and rejection of new cultural offers” (p. 68).

Modern migrations of the youth Ukrainians are of economic and educational character (Semiv \& Hvozdovych, 2012; Mishchuk \& Grishnova, 2015). The problem lies in social and cultural differences. The researchers refer to the processes such as integration, separation, marginalisation, assimilation, adaptation, or acculturation. The available literature devotes little space to adaptation, which, according to Słownik języka polskiego [Polish Language Dictionary], is defined as "adjusting to new social environment, to new conditions; also: reducing the experience of particular stimuli as a result of their long-term effects" (Szymczak et al., 1988, p. 7). Adaptation is treated as one of the early stages of "entering" 
a new culture. The concept was introduced by Darwin and refers to acquiring the minimal skills to survive. In the context of migration we can talk about economic adaptation to the labour market or social adaptation to interactions of the cultural majority (Budyta-Budzyńska, 2011), which may become the beginning of a multilayered (social, economic, cultural, psychological) process of acculturation (see: Nikitorowicz, 2010, Grabowska, 2010). Acculturation is a concept having its source in anthropology, it is used in the cultural dimension and is understood as being "multi-dimensional and referring to cognitive abilities of behavioural change that boosts the effectiveness of functioning in a new cultural environment" (Błeszyńska, 2012, pp. 517-518). Hence it is related to social and individual activity that aims at adopting to a new culture together with efforts made to maintain the newcomer's identity. The activity is based on openness and sensitivity to basic needs of an individual/a group but also on creating conditions for multicultural interactions serving the function of mutual understanding and cooperation, which furthermore foster self-development and perfection.

What is needed from the perspective of the culture of the country which is visited by an ever-growing number of migrants is a policy that promotes cultural and multicultural competence of its citizens. The sphere of education is the first, most prominent factor which can change the attitudes towards the Other. According to Błeszyńska: “The available studies on schools attended by migrants’ children show that these institutions undertake numerous and valuable initiatives to support foreign students" (2012, p. 518), however "their staff is characterised by a feeling of incompetence caused by insufficient knowledge of how their students, or culturally heterogeneous groups, function” (2012, p. 518). Recognition of the cause of incompetence and implementation of specific actions, based on rich experience and well-founded studies in Poland, ${ }^{2}$ cannot go unnoticed and not be included in the educational curricula. Systemic support for teachers will become the green light to take some multicultural steps in education. Teachers gain knowledge and acquire skills at their own expense, often through workshops offered by non-governmental organisations and (rarely) by the Board of Education or the Centre for Educational Development.

Highlighting the role of schooling and teachers in the context of adaptation and acculturation of the foreign youth is an attempt to draw attention to the role of educational institutions responsible for shaping educational priorities, which

What I have in mind is the accomplishments of academic centers in Poland, offering studies dealing with processes and phenomena taking place at the border of and in the context of migration, identity formation, multicultural and intercultural education. 
do not clearly specify the range and standards of multicultural and intercultural competence of teachers and, consequently, of students.

\section{METHODOLOGY}

Migration fosters a culturally diversified social structure of the city of Lublin. At the same time, Lublin's multicultural history forms the foundations to build bridges between its citizens and more and more newcomers. The task of building bridges was taken upon by the institutions of the City Office, cultural institutions, non-governmental organisations, universities, schools, all through creating conditions of mutual understanding and integration. ${ }^{3}$ It should be mentioned that foreigners' education in Poland is regulated by the Ordinance of the Minister of Education of 23 $3^{\text {rd }}$ of August 2017 Concerning Education of Non-Polish Citizens and Polish Citizens Who Were Educated in Foreign Institutions (Journal of Laws from $31^{\text {st }}$ August 2017, item 1655).

The most numerous and noticeable foreign group in Lublin are Ukrainian citizens. These are workers, students of universities and secondary schools. The objective of this study was to survey the opinions of Ukrainian students on their life and social functioning in a culturally different environment. The research topic was formulated as follows: How do Ukrainian students assess their sociocultural adaptation in Poland?

An analysis of the above-mentioned issue requires a focus on its particular aspects: Why did Ukrainian students make a decision to start education in Poland? What is their opinion on their new educational environment? How do Ukrainian students spend their free time? How do they cope with parting from their dearest and nearest? What is their opinion on the Polish society? What differences and similarities do they perceive between the Ukrainian and Polish culture? What Polish values do they deem particularly important?

A questionnaire method was used in order to assess the level of adaptation of the Ukrainian youth in the Polish socio-cultural space. The questionnaire was designed for this purpose and had a diagnostic character - descriptive.

25 students living in a boarding school participated in the study (16 women and 9 men aged 15-19). 13 of them came from big cities in Ukraine, 7 participants came from little towns and 5 participants came from rural areas. Most of them

3 It is a broad issue that deserves a separate discussion. "Multicultural Lublin”, "Say No to Gossip”, “Ukraine in the Center of Lublin” festival, “Lublin Learns Ukrainian” campaign, workshops, trainings, academic courses are only a few of the integration initiatives. 
(19) have been studying in Lublin for a few years (6 participants for 4 years, 9 participants for 3 years, 9 participants for 2 years). Only one person has been studying in Lublin for one year. The most popular university major was logistics (17 participants); the other ones were information technology (3), tourism (3), hotel management (1), and mechatronics (1).

Collecting information and observations, which helped to provide an insight into the functioning of Ukrainian students in the Polish educational system and a new socio-cultural environment, served mostly to determine the most urgent problems and places in the multicultural space which can divide but also connect people.

\section{RESULTS AND DISCUSSION}

In the light of the undertaken study, an interesting result was to discover why the Ukrainian student made a decision to study in Poland. Such an educational decision requires to think over many favourable and unfavourable factors, e.g., conditions of the departure and stay in Poland, potential problems, challenges, etc. A source of information are usually those with migration experience. The Ukrainian students were asked if any one of their family or friends is studying/studied or is working/worked in Poland. Each of the interviewees named such a person. They studied or worked in cities such as Radom, Warsaw, Lublin, Katowice, Cracow, Kielce, Koszalin, Szczecin.

The interviewees were asked about their motivation for studying in Poland. The responses ${ }^{4}$ were as follows: "My mother wanted me to study in Europe"; "When I finished the $9^{\text {th }}$ grade, my parents and I chose a school for me in Poland. Poland offers a higher level of education and a greater chance to get a job in the future"; "My mom said so"; "My mom told me to go to Poland"; "I wanted to study in Poland because it is our neighbour. My mom told me that I should strive for better things in life and I moved to Poland"; "I wanted to study abroad and Poland was an option"; "I saw an advert about studying in Poland”. It can be concluded then that studying in Poland is treated by the Ukrainian students as an investment in the future, an increased chance to get a job, supported by the family.

Arriving to a foreign country for educational purposes is strictly connected with linguistic competence. The interviewees were asked about this aspect of

The responses were corrected in terms of their linguistic style. It did not affect the results of the study. 
being prepared to study in Poland. Almost all the participants (24) devoted some time to learn Polish before arriving to Poland, mostly on language courses. A few participants had individual lessons with a teacher, and only one participant started learning Polish upon arrival. The time they devoted to learning Polish ranged from two months to twelve months. Here are some responses: "I enrolled on a Polish course"; "Polish course"; "Polish course in Ukraine"; "I attended private lessons"; "I had Polish lessons with a teacher"; "I attended extra classes in Ukraine. I was taught by a teacher of Polish who lives in Ukraine. It lasted half an hour"; "I had private Polish lessons, first in a group, then individually"; "I joined a course and then had a private tutor"; "I had private lessons, I read in Polish, watched Polish movies and listened to Polish music"; "Through courses and in Poland"; "I learnt Polish when I arrived to Lublin and started communicating with people”. Studies on migration confirm the role of linguistic competence and of networking with those with migration experience, viewed as cultural capital facilitating the entrance into a new environment and solving some potential difficulties.

An important moment in everyone's life is the moment of being immersed in a new environment, with new cultural and social standards. The study focused on aspects of Ukrainian students' functioning in a new educational environment. The interviewees were asked to point towards differences and similarities between the Polish and Ukrainian schools as well as to address the level of their command of Polish in class and in communication outside school.

Each interviewee made a comment on the Polish educational system, starting from criticism of the system itself, through criticism of teachers, students, and the use of the school space. Here are some critical comments: "Evaluation system, teaching itself”; "Teaching. I learn the same things now in secondary school in Poland as I learnt in primary school in Ukraine"; "Evaluation system expressed through percentage points, short breaks”; “Teachers' attitude towards students”; “Teachers' behaviour towards Ukrainian students, a lot of work”; "Learning with the use of computers"; "Sitting on the staircase"; "Everyone speaks Polish. I have never heard so many people speak Polish”. They also argued: "Ukraine is better”; "Bad teachers"; "Everything is similar, apart from the evaluation system, classes starting from 8:00, and more material to learn”; "Everything is the same apart from religious education in school". The perceived differences may stem from individual experiences of the interviewees or from the culture of the schools they attended.

The questionnaire also addressed the issue of school subjects which cause most difficulty and those which give satisfaction. More than a half of the interviewees (14) pointed to Polish or history as school subjects causing most difficul- 
ties. Both of these subjects were mentioned by 10 interviewees. Some other school subjects were: mathematics (5), physics (10), and vocational subjects (7). Only one person stated that they find no difficulty in any school subject. On the other hand, among most popular school subjects were vocational subjects (18), physical education (6), foreign languages (5), Polish (3). It can be assumed that these were subjective preferences of the interviewees. A high percentage of humanistic subjects being considered difficult may be viewed as a consequence of a lack of rudimentary knowledge of the Polish history, which is not present in Ukrainian coursebooks and curricula. The Polish language is a foreign language for Ukrainians, and secondary schooling requires an advanced command of the Polish language and literature.

The Ukrainian students were questioned whether because of a poor command of Polish, they have more difficulty in understanding school instructions, doing homework, communicating with peers or performing in class. The collected data suggest that the difficulties in learning Polish are solved with the help of Polish teachers, Polish and Ukrainian friends. This is a positive aspect of adaptation to a new culture. 7 interviewees pointed to the Internet and Google translator as a source of help. ${ }^{5}$ Ukrainian students also admitted that they practise Polish while talking to Polish teachers and classmates. None of the interviewees mentioned extra Polish classes, which is schools' statutory obligation.

Preparation to classes takes a substantial amount of time, i.e., 4 hours a day, according to the interviewees. Obviously it is dependent on the amount of material needed to become familiar with before classes, as well as on the tests or examinations. None of the interviewees mentioned language or cultural differences as a factor impeding preparation for classes.

An important aspect of the Ukrainian students' adaptation was their opinion on their functioning in an out-of-school environment, i.e., the boarding school, the city, among the Polish society. The questions concerned ways of spending free time, including holidays in Poland, as well as reactions from classmates, those living in the boarding school, or Lublin citizens to their stay in Lublin.

Ukrainian students responded that they spend their free time: "going for a walk"; "doing sports”; "watching movies”; "learning languages”; "surfing the Internet”; "reading or listening to music”; “meeting friends”; “drawing or painting”; "playing computer games”; "playing the guitar”. They were also asked about how

The interviews with the teachers reveal that foreign students quite often use Internet dictionaries in class in order to better understand the material. It is the only situation of using mobile phones in class which is allowed [according to the interviews with several teachers from one of the vocational schools in Lublin]. 
they spend weekends and holidays in Poland. The most frequent answer was that they meet their Ukrainian friends and go out. Other answers included: "If there are some festivals in Lublin, I take part. If not, I just walk around the city”; "A walk, going out to a shopping gallery”; "I study or surf the Internet”; "I play football, go out to the city centre, I study". These answers point towards a preference of cultural anonymity, which does not mean, however, an ease in moving around the city's space. ${ }^{6}$ It should be noted that most of the interviewees (20) stated that they have both Ukrainian and Polish friends. It is a positive aspect of functioning in a culturally new environment. Only four interviewees pointed to having no Polish friends, and one person left the question out. The most frequent responses to the question of ways of spending free time with friends were: "we play games"; "we just spend time together”; "we talk”; "we play football”; "we play computer games, go for a walk, chat”; "we study”; "we discuss interesting issues”; "we talk business"; "we do homework, communicate, I teach them Russian, they teach me Polish"; "I have a Polish boyfriend, two male friends and girlfriends"; "we watch movies". Five interviewees did not respond to the question.

The Ukrainian students were asked about their ways of spending Polish holidays. All the interviewees who responded to the question (21) stated that they come back to Ukraine to spend the time with their families. For them, the Polish holidays are time off school when the boarding school is closed. This forces them to come back to Ukraine. One interviewee claims that he/she takes part in holiday parties organised in the boarding school. This response points to the need of creating and participating in holiday events by the Polish and Ukrainian community, which fosters mutual understanding, feelings of respect, recognition, creating comparisons, and building cultural bridges. One interviewee mentioned some problems or limitations existing in this area, however, such a claim is not statistically reliable. This aspect will require further studies.

Parting from the dearest and nearest, a long stay away from home was an important issue in the study, in the context of functioning in a new culture. The Ukrainian students were asked about things they miss most in Poland. The responses were: "My house"; "Family"; Parents, those close to me"; "Ukrainian friends"; "My boyfriend”; "My boyfriend, parents"; "Nice weather, free time, independence"; "Money, free time”; "Family, Ukrainian friends, understanding”; "Everything is ok"; "Some stuff from home"; "My parents, Ukrainian friends, there are so many limitations here"; "Privacy in the boarding school"; "Good interns in the

Ukrainian minority can be spotted mostly in big supermarkets and public means of transport, where they can be distinguished through the language they use. 
boarding school"; "My flat (home)". Three interviewees stated they did not miss anything, five interviewees did not respond at all. The interviewees highlighted the need of independence, understanding, privacy, which they do not have in the boarding school. It is worth noting that the studies show that also Polish students express some dissatisfaction with living in the boarding school. The place itself can be characterised by imposing certain limitations on the students which require reorganisation of their private lives (Okrasa, 2017, pp. 208-209). It may be difficult to determine whether the Ukrainian students experience some difficulties due to some problems with adaptation to a new socio-cultural environment or just due to the specificity of the place.

Difficulty in adapting to the new environment can be deepened by missing one's family in Ukraine. The interviewees were asked to specify what they do when they miss home, and how often they are in touch with their family. The responses show that the Ukrainian students miss their families much and quite frequently they are in touch with them by means of phone conversations or Internet applications. Some of the responses have an emotional undertone: "I phone mum and dad and we chat. I look at their photographs"; "I look at their photos when I miss them"; "I send messages or phone them. Sometimes I cry"; "I tell my mum how I miss her and how I would like to see my dad and hug him"; "I cry because I have no choice, I visit home so rarely". There are, however, some answers which point to frequent visits: "I often go home and do not miss home much”; “I go home [when I miss my family]". Some responses demand a deeper pedagogical reflection: "I do not miss them any more"; "I got used to not missing them"; "I play". The data show that 14 interviewees keep in touch with their families everyday, 6 interviewees do it 2-3 times a week, and 5 interviewees do it once a week. Mostly they keep in touch over the phone, through Skype and Facebook. 14 students do not stick to one but rather make use of various means of communication. The frequency of contact is a significant sign of their feeling of loneliness and the need of support from the family.

The reactions from the environment to Ukrainian students' stay in Lublin was another issue taken under scrutiny in the study in the context of adapting to a new culture. The students were asked if they experienced any negative situations in Lublin. 14 interviewees stated that they did while 11 interviewees did not. If the answer was affirmative, the students were asked to describe the situation. Only eight of the interviewees decided to do this, with descriptions such as: "I have some Polish classmates who always talk bad about Ukraine and I couldn't stand it. I started shouting at them but no one from Ukraine supported me”; "A Polish drunkard shouted at me and used vulgar language"; "Some people talked bad 
about my nationality; they said nasty things about Ukraine and Ukrainian people"; "They made me feel uncomfortable"; "Mostly that I was from Ukraine and they did not like it”; "They spoke bad about our culture. They shouted that we should come back to our country. I do not want to meet these people again"; "I would rather not talk about it, sorry"; "They were rude when they talked about Ukrainian people. The guy spoke loudly on the bus about Ukrainian people. I avoid conflict with such people”. Despite the fact that only a third of the interviewees shared their thoughts, feelings, and stories, they clearly point towards negative feelings towards and act of discrimination against Ukrainian community. Only three interviewees confessed to have discussed the negative situation with their friends, teachers, or those in charge of the boarding school.

Cultural differences are observed mostly in everyday communication, which, on the one hand, may arouse some curiosity, yet on the other hand may lead to some negative attitudes. The Ukrainian students were asked about the assessment of their own behaviour related to their national culture, which may be not understood by their Polish friends. 10 interviewees addressed the question, the remaining participants of the study responded “I don't know”. It may result from their reluctance to take their own behaviour under scrutiny. Out of those who responded to the question, two stated that Poles "understand everything” or "a lot", and the next two interviewees drew attention to their use of Ukrainian while in the company of Polish friends: "I don't always use Polish but Ukrainian. They get angry because they don't understand what I'm talking about”. Two interviewees pointed to humour as a source of misunderstanding. One person claims: “They don't like me when I get better grades than Polish students, e.g., I have good grades in Polish while some other students get unsatisfactory grades”.

The questionnaire answers show another aspect of adaptation, i.e., a lack of knowledge of and interest in the Polish culture. The Ukrainian students were asked about their feelings, thoughts, observations on the Polish society and noticeable cultural differences. Only half of the interviewees addressed this question. The most frequent answers were quite laconic: "Everything is fine"; "Different culture", "Many things"; "Humour", other focused on some negative experiences: "When they speak bad about Ukrainians and laugh at our political situation, or feel superior to us"; "They treat us in a derogatory way. They are egoists, I met a lot of them here"; "Lots of Polish people are egoistic"; "They bully foreigners"; "Why do Poles (not everyone) not like Ukrainians?”; “They insult Ukraine. They always complain, even about Poland". There were some comments on the dressing code: "Clothes, Poles do not dress nice", and style of communication: "Why do they swear so often?”. 
Another question concerned those elements of the Polish culture which seem particularly interesting to the Ukrainian students. One of the answers was "many things", which testifies to the presence of such elements. Only a few students pointed towards specific elements related to the Polish culture or tradition. These elements are: "The Church, communion, etc.”; "Fat Thursday, Easter”; "Boy’s Day"; "I like theatres in Poland"; "Paintings"; "Culture, education”. Two responses focused on similarities: "They [elements] are similar to those in Ukraine”; "Practically, we live in the same culture". The answers also encompassed dishes which are enjoyed by the students, such as 'żurek' (traditional Polish soup made from fermented bread or rye flour), or all kinds of meat. Dishes which do not appeal to the Ukrainian students were: sweet dumplings, potato dumpling, rice with cream, which are served in the boarding school. One interviewee wrote: "Ukrainian borsch is not cooked the way we make it".

The interviewees were asked about their opinions on shared values between the Polish and Ukrainian culture. They responded: "Almost everything is the same, we are neighbours. We value our history, solidarity, customs”; “Our cultures are similar"; "We have similar languages and traditions". These were the opinions of the students who have been staying in Poland for three years. Other interviewees pointed to: "faith in God”; "8th of March"; "Polish language”; or to some general statements such as: "they are different"; "they are similar". Almost half of the interviewees (12) wrote "I don't know". The attitude of openness to the differences and similarities between cultures is vital for strengthening the feelings of respect and understanding in the process of multicultural exchange and integration. When presented in the background of another culture, values of one's own culture become more prominent and become a source of ethnic identity which get more noticeable with time spent away from one's culture. The Ukrainian students were asked about values important for their own culture. Only 11 interviewees responded, out of which 2 wrote "I don't know", and one wrote that there are many. The remaining eight participants wrote: "embroidery, songs, hymn, Tryzub [the state coat of arms of Ukraine]”; "history of my country, its traditions"; "liberty, solidarity”; “decency”; “education”; “language, songs”; “faith in God, respect to family”. One person with a three-year stay in Poland wrote: "Don’t forget about your homeland while you're abroad".

The highlighted values should be taken into consideration while creating a program for mutual understanding and preparing multicultural workshops for the students and everyone living in the boarding school. The school's and boarding school's space and culture is a place where the process of internalising the elements of the Polish culture by the Ukrainian students should take place in order 
to facilitate "a chance to identify, differentiate and selectively adapt the patterns and values characteristic of the source and target culture and to form a culturally complex identity” (Błeszyńska, 2012, p. 535).

\section{SUMMARY}

The phenomenon of meeting members of different cultures poses a specific cognitive challenge for a researcher, and an area to study the habitus of students coming from a different culture, and to shape the process of their integration. Teachers, on the one hand, have an opportunity to observe the course and effects of multicultural meetings, on the other hand, they have all the conditions to actively participate in the process of interaction, communication, creation of dialogue (polylogue), and to share (multicultural) competence, develop them and acquire new ones. Such a role of teachers is determined by transterritorial processes, in which they take part and which they create.

The performed study shows aspects of the Ukrainian students' stay in Lublin. We tried to expose these areas which require some attention in the context of adaptation (and acculturation) and consequently demand further, detailed studies, e.g., in the form of interviews with the Ukrainian youth, teachers at schools and workers of dormitories. The diagnosis helped to discern both positive and negative factors of the Ukrainian students' stay in Lublin.

Viewing the Ukrainian students from the perspective of the process of adaptation leads to the following conclusions:

Arrival of young Ukrainian students to Poland for educational purposes was a thought-over decision made together with the family. Almost all of the students were prepared to migrate by participating in Polish language courses. They have also had some family or relatives with history of migration to Poland, who could share their experience.

The Ukrainian students observed many differences in the way Polish schools function, starting from the system of education itself, through students' and teachers' behaviour. Each participant pointed to the school subjects they enjoyed and did not enjoy. These belonged to the sciences, humanistic studies and vocational subjects. It seems to be correlated with the students' individual preferences and interests. Difficulties in learning Polish are solved with the help of Polish teachers, Polish and Ukrainian friends, as well as the Internet. None of the participants made use of extracurricular classes organised by the school or boarding school. 
Free time is devoted to pursuing hobbies, studying or exploring the city. The students spend the time with their Ukrainian friends or take some individual activity. Only few of them spend free time with Polish peers. During Polish holidays, the students come back home in Ukraine. When the students miss their family, they keep in touch over the phone or through social media. The questionnaire reveals that the students experience loneliness and require emotional support throughout the students' stay in Lublin.

The students were subject to verbal discrimination during their stay in Lublin, and they are unwilling to talk about the problem. Some of them received support from their friends or teachers, with whom they shared their stories.

The Ukrainians point towards language and national identity as sources of cultural differences, which lead to the Polish society being biased. The majority of the interviewees did not respond to the question asking for a comparison of the Polish and Ukrainian culture. Their opinions were of a general character and concerned the area of popular customs and traditions. The values perceived as being shared by the two cultures are: neighbourhood, history, language, faith, traditions. Differences concerned religion, customs, songs, symbols.

The collected data is an important indication to intensify actions aimed at building a society open to new cultures and at shaping interaction in the multicultural space. The systemic educational policy of schools should be directed at both Polish and Ukrainian students and teachers. It should be realised with the help and support of national institutions. One of the forms of support could be incorporating multicultural education in the core curriculum of the Ministry of Education and in the annual educational priorities within schools.

\section{References}

Błeszyńska, K. (2012). Między stereotypem a doświadczeniem drogi. Dydaktyka różnicowa wobec kształcenia dzieci migrantów. In: A. Szczurek-Boruta, \& E. Ogrodzka-Mazur (Eds.), Poza paradygmaty. Pedagogika międzykulturowa. Księga pamiq̨tkowa dedykowana Profesorowi Tadeuszowi Lewowickiemu. Vol. 2 (pp. 516-544). Toruń: Wyd. Adam Marszałek.

Budyta-Budzyńska, M. (2011). Integracja czy asymilacja? Polscy imigranci w Islandii. Warszawa: Wyd. Scholar.

Grabowska, B. (2010). Strategie kulturalizacyjne członków mniejszości narodowej. In: T. Lewowicki, \& E. Ogrodzka-Mazur (Eds.), Edukacja międzykulturowa-teorie, poglądy, doświadczenia społeczne (pp. 162-187). Cieszyn-Warszawa-Toruń: Wyd. WSP ZNP, WEiNoE UŚ, Adam Marszałek.

Hofstede, G. (2007). Kultury i organizacje. Warszawa: Wyd. PWE. 
Mishchuk, H., \& Grishnova, O. (2015). Empirical Study of the Comfort of Living and Working Environment - Ukraine and Europe: Comparative Assessment. Journal of International Studies, 8(1), pp. 67-80. DOI: 10.14254/2071-8330.2015/8-1/6.

Nikitorowicz, J. (2010). Teoria akulturacji w badaniach międzykulturowych. In: T. Lewowicki, \& E. Ogrodzka-Mazur (Eds.), Edukacja międzykulturowa - teorie, poglądy, doświadczenia społeczne (pp. 15-28). Cieszyn-Warszawa-Toruń: Wyd. WSP ZNP, WEiNoE UŚ, Adam Marszałek.

Nikitorowicz, J. (2017). Etnopedagogika w kontekście wielokulturowości i ustawicznie kształtujq̨cej się tożsamości. Kraków: Wyd. Impuls.

Okrasa, M. (2017). Bursy i internaty szkolne w województwie lubelskim w latach 1918-1998. Lublin: Wyd. UMCS.

Ordinance of the Minister of Education of 23 ${ }^{\text {rd }}$ August 2017 Concerning Education of NonPolish Citizens and Polish Citizens Who Were Educated in Foreign Institutions. Journal of Laws from 31 ${ }^{\text {st }}$ August 2017, item 1655.

Semiv, L., \& Hvozdovych, Y. (2012). The Intellectual Migration of the Youth in Ukraine: The Backgrounds for "Brain Circulation”. Journal of International Studies, 5(2), pp. 72-81. DOI: $10.14254 / 2071-8330.2012 / 5-2 / 8$.

Szymczak, M. et al. (Eds.) (1988). Słownik języka polskiego. Vol. 1. Warszawa: Wyd. PWN. 